\title{
Zárt és nyitott cellás szerkezeti formák vizsgálata végeselem-analízissel
}

\section{Evaluation of closed and open-cell structural lattices with finite element analysis}

\author{
Kulcsár Klaudia, ${ }^{1}$ Kónya János ${ }^{2}$ \\ Dent-Art-Technik Kft. Győr, Magyarország \\ ${ }^{1}$ kulcsar.klaudia@dentarttechnik.hu \\ 2janos@dentarttechnik.hu
}

\begin{abstract}
Four lattice structures based on well-known crystal structures were evaluated in this study using the finite element method. Simple cubic, face-centered cubic, body-centered cubic, and diamond structural alignments were used to build up lattices from the body volume. Modern-day implant development trends are shifting towards additive manufacturing technologies, which have the advantage of creating structures that can improve the biological stability of implants that have integrated scaffolds. Such scaffolds can be trabecular structures that mimic bone tissue and facilitate tissue penetration into the porous parts of the implant. The final purpose of our study is to create an implant system that promotes the process of osseointegration. Evaluations have been carried out using finite element analysis.
\end{abstract}

Keywords: closed cell structures, open cell structures, finite element analysis, crystal structures.

\section{Összefoglalás}

A tanulmányban a négy legismertebb kristályrácstípus-felépítésnek megfelelően kialakított cellás szerkezetet vizsgáltuk végeselem-analízis segítségével. A testmodellben a cellás szerkezet kialakítása megfelel az egyszerü köbös, lapközepes köbös, térközepes köbös és a gyémántrács szerkezeti felépítésének. A jelenlegi implantátumfejlesztések egyre inkább nyitnak az additív gyártási eljárások felé, melyek előnye, hogy segítségükkel olyan szerkezeti formákat lehet létrehozni, amelyek növelhetik a beépített implantátumok biológiai stabilitását. Ilyen szerkezeti forma a csontszövetutánzó, trabekuláris szerkezetek, melyek lehetővé teszik a csontszövet behatolását az implantátum porózus részeibe. Kutatásunk célja, hogy olyan implantátumrendszert hozzunk létre, amely elősegíti az osszeointegráció folyamatát. A vizsgálatokat végeselem-módszerrel végeztük.

Kulcsszavak: zárt cellás szerkezetek, nyílt cellás szerkezetek, végeselem-analízis, kristályszerkezetek.

\section{Bevezetés}

Az ortopéd sebészetben a sejtszerkezeteket háromdimenziós porózus biotermékként használják, amellyel kísérletet tesznek a csont szerkezetének, valamint müködésének utánzására [1]. A porózus biológiai anyag felhasználható csontpótlóként, amelyet úgy kell megtervezni, hogy a csont tulajdonságaival megegyezzenek a mechanikai tulajdonságai. Emellett figyelembe kell venni a többi tényezőt is, amelyek elősegítik a csont növekedését, pl. azt, hogy a csontszövetet utánzó, cellás szerkezet permeabilitása befolyásolhatja a sejtek vándorlását [2]. Az elmúlt két évtizedben számos tervezési elvet javasoltak a csontszövetet 
helyettesítő szerkezetek tervezésére, ahol figyelembe veszik a mechanikai tulajdonságokat, a biokompatibilitást és a biológiai funkcionalitását [3, 4]. A legtöbb tanulmányban a porózus szerkezeteket titánötvözetekből készítik, viszont a titánötvözetek merevek és meghaladják a csont mechanikai tulajdonságait [5]. A csont és titánötvözet közötti mechanikai eltérés akadályozhatja a csont növekedését és csontfelszívódást válthat ki, ami előidézheti az implantátum meglazulását [6, 7]. A cellás szerkezetek előállítása additív gyártással történik, ezek mechanikai tulajdonságai közelebb vannak az emberi csont mechanikai tulajdonságaihoz [5, 8, 9].

Az utóbbi időben népszerüvé vált az additív gyártás, amelyet gyors prototípusként vagy 3D nyomtatásként is említ a szakirodalom. A végtermék rétegről rétegre épül fel [10]. A szelektív lézerolvasztást, rövidítve SLM, sikeresen fejlesztették ki az elmúlt időben a fémporok összeolvasztására, az SLM technológiával gyártott darabok viszonylagos sürüsége meghaladhatja a 99\%-ot [11]. Az implantátumokhoz felhasznált tiszta titánt és titánötvözeteket csontpótlásra alkalmazzák, mivel kiváló mechanikai tulajdonsággal és biológiai tulajdonsággal rendelkeznek [12]. Az implantátumokat készítik más, biokompatibilis anyagokból, mint például Co-Cr ötvözetből és rozsdamentes acélból. Ezek rugalmassági modulusa összehasonlítva a titánötvözetekével, az utóbbié kisebb, de még mindig jóval magasabb az emberi csont rugalmassági modulusánál [13]. Ahmaid és társai a szelektív lézeres olvasztás (SLM-) módszerét és Grade23 titánport alkalmaztak vizsgálataik során, és 6-féle rácselemet, amelyek a következők voltak: kocka, gyémánt, megcsonkított hexaéder, megcsonkított kuboktaéder, rombikus dodekaéder és rumbikuboktaéder. A vizsgálatokhoz hengeres próbatesteket gyártottak az előbb említett cellás szerkezeti formákból, majd nyomóvizsgálatot végeztek rajtuk [14]. Chen és társai tanulmányukban különböző porozitással kialakított, nyíltcellás modelleket elemeztek. Ennek során azt vizsgálták, hogy a CAD-programban tervezett porózus szerkezethez képest az SLM-technológiával gyártott mintákon milyen eltérés következik be. Például a $80 \%$ porozitású CAD-modell a valóságban, nyomtatást követően csak 71\%-os porozitású lett [15].

\section{A szerkezetek ismertetése}

A kutatás fő célja, hogy egy olyan cellás szerkezetet hozzunk létre, amely az implantátum beültetését követően javítja és gyorsítja az oszszeointegrációs folyamatot az implantátum és a csont között. Korábbi tanulmányainkban már kísérleteztünk, ahol kristályrácsok alapján terveztük meg a kiinduló testeket, amelyek 20×20×20 mm-es kockák voltak, a mostani tanulmányban pedig ezeket vizsgáljuk olyan környezetben, ahol 60×60×60 mm-es kockákat alkottunk a kisebb kockákból.

\subsection{Egyszerü köbös szerkezeti felépítés}

Az egyszerű köbös szerkezeti felépítés $20 \times 20 \times 20$ mm-es kockákból áll, amelyeknél a sarokpontokban találhatók a kivágott gömbök középpontja, ezek átmérőjét fokozatosan növeltük 0,1 mm-rel; a térfogatcsökkentés fázisai az 1 . ábrán láthatók. A kristályszerkezet negatívjával modelleztük a cellás szerkezetet. A felső felszínt síknak hagytuk, így azon nem vágtunk ki gömböket. A kivett gömbök nagyságával értük el a térfogatcsökkentést. Az egyszerü köbös szerkezetnél a zárt cellás szerkezet nem vált nyílttá, így csak kis térfogatcsökkentés érhető el ebben az esetben.

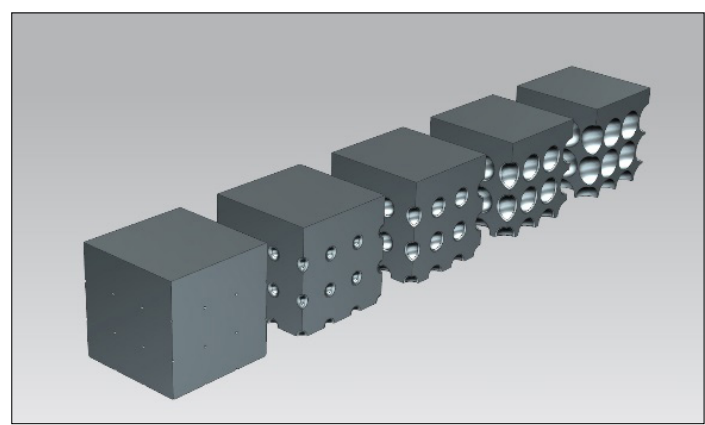

1. ábra. Az egyszerü köbös cella szerkezeti felépítésének kialakítása a testmodellben

\subsection{Lapközepes köbös szerkezeti felépítés}

A lapközepes köbös szerkezeti formánál a kivett gömbök középpontja a sarokpontokon és az oldallapokon található, a felső felületen a sarokponti gömböket nem vettük ki, hogy a felső felület teljesen sík maradjon. A kristályszerkezet negatívjával modelleztük a testet. A 2. ábrán a lapközepes köbös szerkezeti forma térfogatcsökkentési fázisai láthatók. Ennél a kialakításnál észrevehető, hogy nyílt cellás szerkezetté válik, így nagy térfogatcsökkentés érhető el. A gömbök nagyságát ebben az esetben is 0,1 mm-es lépésenként növeltük. 


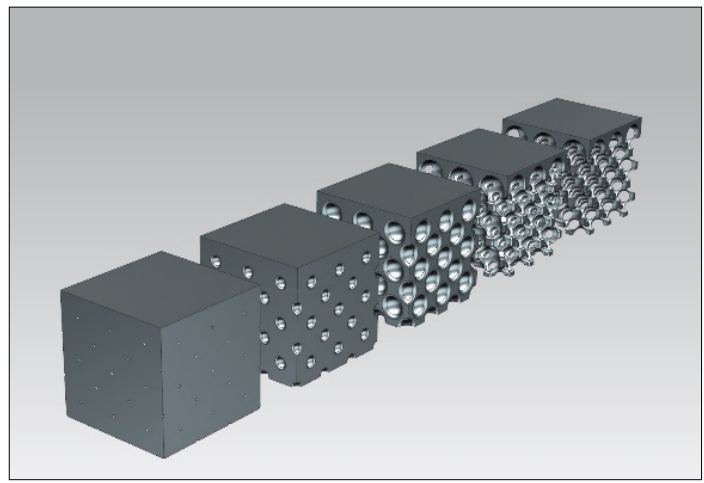

2. ábra. Lapközepes köbös cellaszerkezet-kialakítás a testmodellben

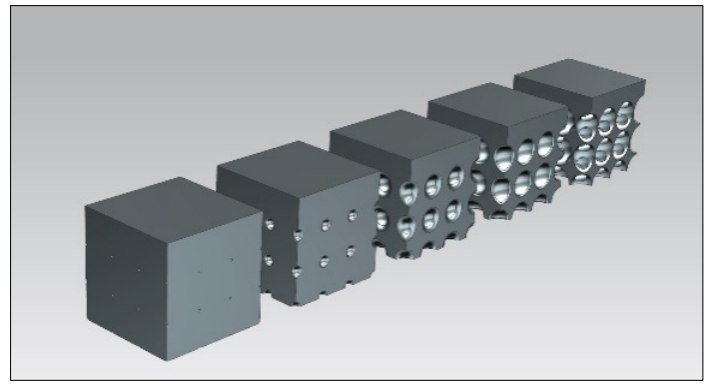

3. ábra. Térközepes köbös cellaszerkezet-kialakítás a testmodellben

\subsection{Térközepes köbös struktúra}

A térközepes köbös szerkezeti forma kialakításánál a sarokpontokban és a $20 \times 20 \times 20 \mathrm{~mm}$-es kockák középpontjaiban találhatók a kivett gömbök középpontjai. Ennél a megoldásnál is a felső felület sík, annak köszönhetően, hogy az ott található sarokpontokon nem vettük ki a gömböket. A kristályszerkezet negatívjával modelleztük a testet. Ebben az esetben is 0,1 mm-es lépésekkel növeltük a kivágott gömbök nagyságát. A 3. ábrán a térközepes köbös szerkezeti forma térfogatcsökkentési fázisai láthatók. Észrevehető, hogy ez a szerkezet is nyilt cellás szerkezetté vált, így nagy térfogatcsökkentést értünk el.

\subsection{Gyémántrácsos szerkezeti felépítés}

A gyémántrács a lapközepes kockarács alapján épül fel, vagyis a kivett gömbök a sarokpontokon és a kis kockák oldallapjain találhatók, és ehhez még a változó térnyolcadok közepére illeszkedő gömbök adódnak. A felső felület ebben az esetben is sík, így az egyik térnyolcad belsejéből és a felső sarokpontoknál lévő gömböket nem vettük ki. A kivett gömbök nagyságát itt is 0,1 mm-rel növeltük. A gyémántrács alapú szerkezeti forma térfogatcsökkentési fázisai a 4. ábrán láthatók.

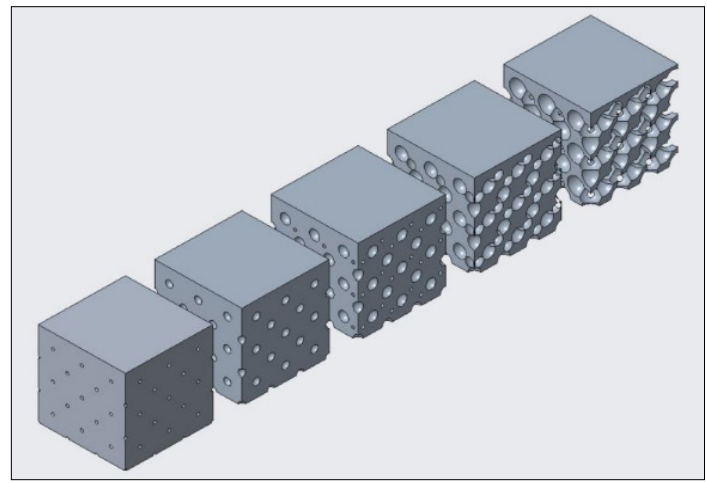

4. ábra. Gyémántrács alapú cellaszerkezet-kialakítás a testmodellben

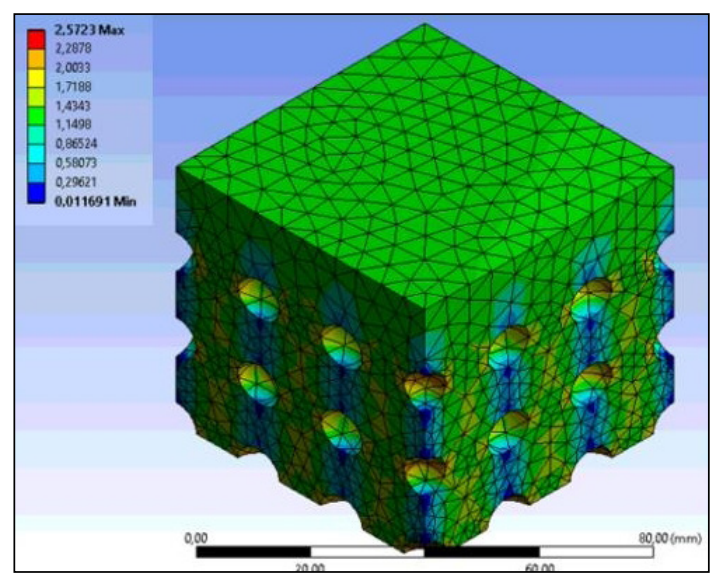

5. ábra. Egész testben ébredő egyenértékü feszültség szemléltetése

\section{A végeselem-módszerrel végzett elemzés eredménye}

A szimulációkat az ANSYS szoftverrel végeztük el. A fent szemléltetett szerkezeti formáknál minden esetben egy $60 \times 60 \times 60 \mathrm{~mm}$-es kocka a végső testmodell, amely $20 \times 20 \times 20$ mm-es kis kockákból áll. A terhelések minden esetben azonos formában történtek: a kocka alsó részén a megfogás, a kocka felső, síkfelületén pedig a terhelés, amelynek nagysága $4500 \mathrm{~N}$ mindegyik modell esetében. Az erő megadásánál megoszló erőrendszert alkalmaztunk, a megfogásnál pedig súrlódásmentes megtámasztást. Az elemzés során először az ébredő feszültséget vizsgáltuk, mely egy hálózott példán látható az 5 . ábrán.

A számításoknál kíváncsiak voltunk arra, hogy a kis kocka miként viselkedik a test közepén, így a középső kis kockában is elemeztük az ébredő feszültséget, mely egy hálózott példán látható a 6. ábrán. 


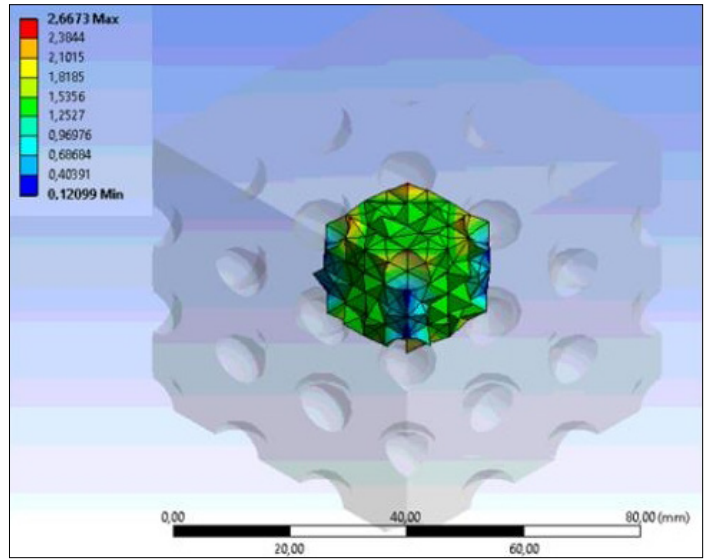

6. ábra. A középső kiskockában ébredő egyenértékü feszültség szemléltetése

Az eredményeket a különböző szerkezeti formáknál összehasonlítottuk, majd ezt követően a teljes testben ébredő feszültséget egymással is összehasonlítottuk, hogy megtudjuk, melyik struktúra eredményei a jobbak.

\subsection{Az egyszerü köbös szerkezeti forma mo- dellezési eredményei}

Az egyszerű köbös cellaszerkezetű testen 199 szimulációt végeztünk, a legkisebb átmérő $0,1 \mathrm{~mm}$, a legnagyobb kivett átmérő pedig 19,9 mm. A 7. ábrán láthatók a mérések eredményei, az egész testben ébredő egyenértékű feszültség maximumának értékei és a középső területen ébredő egyenértékű feszültség maximum értékei szinte megegyeznek. A legkisebb elérhető cellatérfogat-részarány szintje, ami megmutatja, hogy mennyi az adott cellaszerkezetű test térfogatának és kiinduló test térfogatának aránya százalékos formában, csupán 57\% körüli, ahol minimális egyenértékű feszültségérték ébred. Az egyszerü köbös struktúra csak zárt cellás szerkezet.

\subsection{A lapközepes köbös szerkezeti forma modellezési eredményei}

A lapközepes köbös szerkezeti forma esetében 155 szimulációt végeztünk, a legkisebb átmérő 0,1 mm, a legnagyobb kivett gömb átmérője 15,5 mm. A 8. ábrán látható a lapközepes köbös cellaszerkezetű test egyenértékű feszültség maximum értékei. A 32\%-os térkitöltési szintnél magasabb egyenértékű feszültség ébred, ennél a pontnál válik a struktúra zárt szerkezetűből nyitott szerkezetűvé. A lapközepes köbös szerkezeti forma esetében nagy térfogatcsökkentés érhető el, és a feszültség értékei $20 \%$-os cellatérfogat-részarány szint mellett is elfogadhatók.

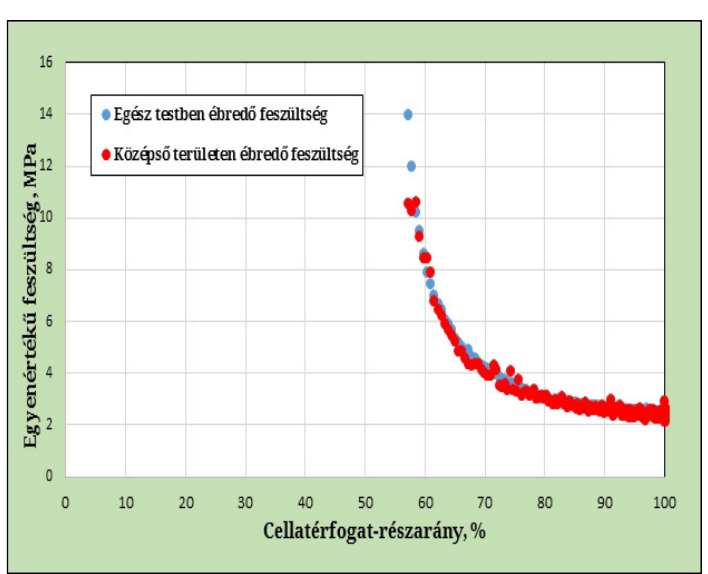

7. ábra. Az egyszerü köbös cellaszerkezeti formában felépitett testben ébredő egyenértékü feszültség a cellatérfogat-részarány függvényében

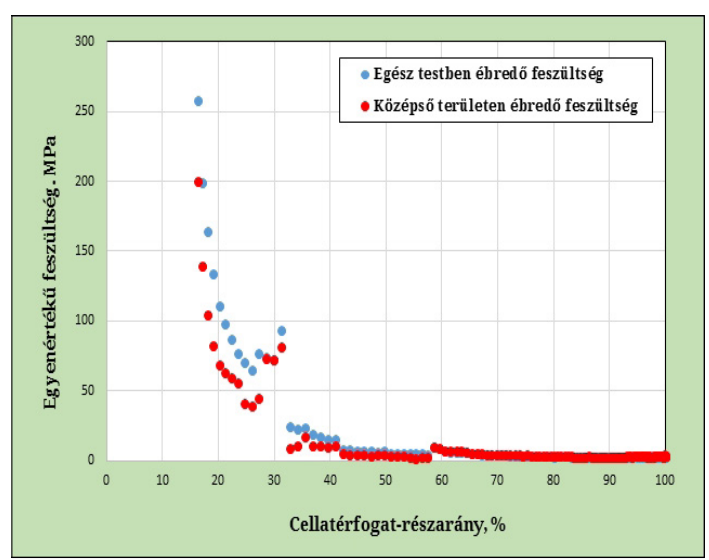

8. ábra. A lapközepes köbös cellaszerkezeti formában felépitett testben ébredö egyenértékü feszültség értékei a cellatérfogat-részarány függvényében

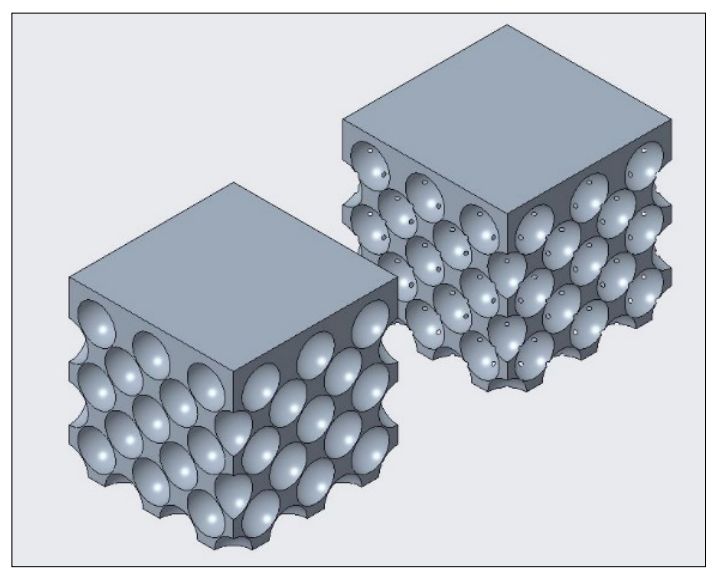

9. ábra. A lapközepes köbös elrendezésü, nyitott cellás szerkezet felépitése 


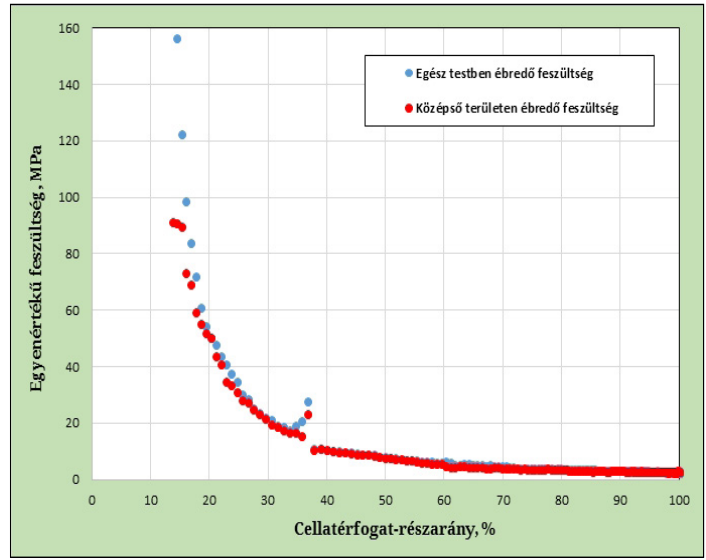

10. ábra. A térközepes köbös cellaszerkezeti formában felépitett testben ébredő egyenértékü feszültség értékei a cellatérfogat-részarány függvényében

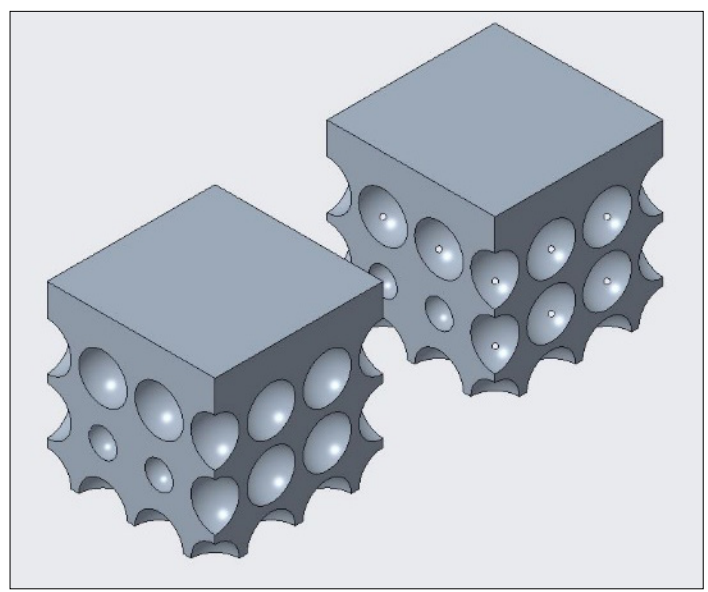

11. ábra. A térközepes köbös elrendezésü, zárt és nyitott cellás szerkezet felépitése

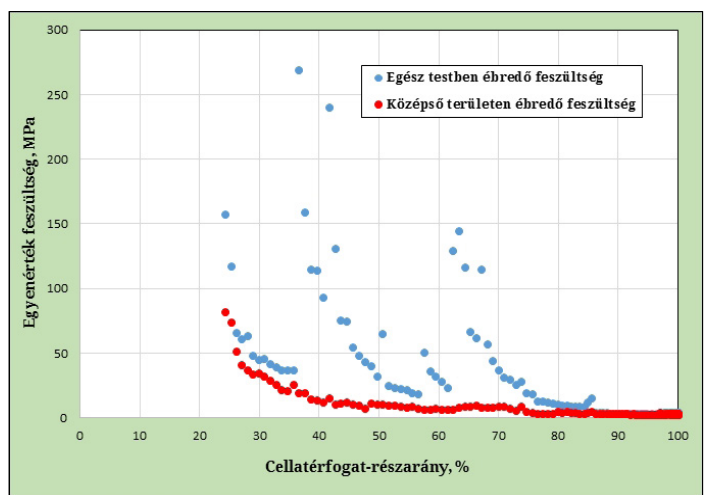

12. ábra. A gyémántrács alapú cellaszerkezeti formában felépitett testben ébredő egyenértékü feszültség értékei a cellatérfogat-részarány függvényében
A 32\%-os cellatérfogat-részarány szintnél vált zártból nyitott szerkezetűvé a cellaszerkezet, a 9. ábrán látható a zárt, valamint a nyitott cellás szerkezet felépítése.

\subsection{A térközepes köbös szerkezeti forma modellezési eredményei}

A térközepes köbös szerkezeti forma esetében 199 szimulációt végeztünk, a legkisebb átmérő $0,1 \mathrm{~m}$, a legnagyobb kivett gömb átmérője 19,9 mm. A 10. ábra mutatja az egyenértékű feszültség maximum értékeit. A 36\%-os cellatérfogat-részarány szintnél magasabb egyenértékű feszültség keletkezik, majd ismét csökkenni fog és újra emelkedni, ennél a pontnál válik a struktúra zárt szerkezetűből nyitott szerkezetűvé. A térközepes köbös szerkezeti forma esetében nagy térfogatcsökkentés érhető el, és az egyenértékű feszültség értékei 13\%-os cellatérfogat-részarány szint mellett is nagyon jónak mondhatók.

A 36\%-os cellatérfogat-részarány szintnél vált zártból nyitott szerkezetűvé a cellaszerkezet, a 11. ábrán látható a zárt, valamint a nyitott cellás szerkezet felépítése.

\subsection{A gyémántrács alapú szerkezeti forma modellezési eredményei}

A gyémántrács alapú szerkezeti forma esetében 132 szimulációt végeztünk, a legkisebb átmérő $0,1 \mathrm{~mm}$, a legnagyobb kivett gömb átmérője 13,3 mm. A 12. ábra mutatja az egyenértékű feszültség maximum értékeit. A 63\%-os cellatérfogat-részarány szintnél emelkedik az érték, ennél a pontnál válik a cellaszerkezet zárt szerkezetűből nyitottá. Láthatunk emelkedést még 57\%-nál is. A gyémántrács alapú cellaszerkezetben a 40\%-os cellatérfogat-részarány szintnél lévő egyenirányú feszültség értékei még elfogadhatók.

A 13. ábrán látható a zárt, valamint a nyitott

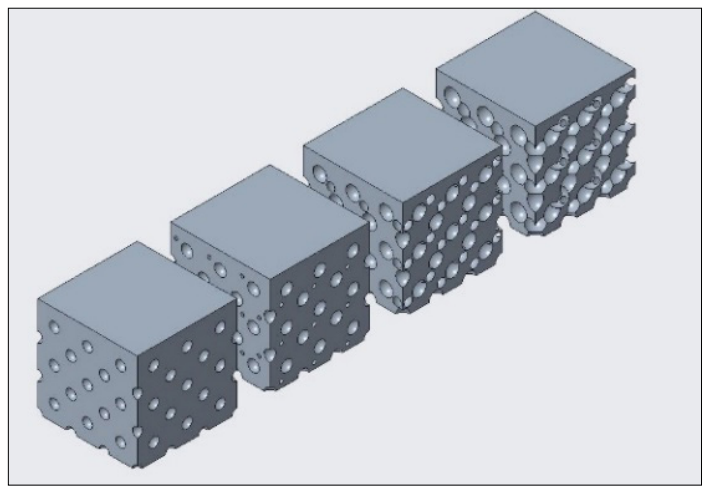

13. ábra. A gyémántrács alapú, zárt és nyitott cellás szerkezet felépitése 
szerkezet felépítése. Észrevehető, hogy ennek a struktúrának több átalakulási szintje van, mint az eddigieknek.

\section{Következtetések}

Az előzőekben ismertetett eredményeket egyesítettük, ezek a 14. ábrán láthatók. A grafikonon az egyszerü köbös, a lapközepes köbös, térközepes köbös kockarács és a gyémántrács szerkezeti formáját követő cellaszerkezetű testekben ébredő, egyenértékű feszültség értékeinek a cellatérfogat-részarány függvényében változó ponthalmazai találhatók. A legkevesebb térfogatcsökkentés az egyszerű köbös cellaszerkezetnél érhető el, ennélfogva nem számít, hogy kis feszültség ébred benne, a test „csak” zárt cellás szerkezet, emiatt irreleváns számunkra ez a megoldás. A cellatérfogat-részarány függvényében a gyémántrács alapú szerkezetben magasabb feszültségek keletkeztek. A lapközepes és térközepes köbös elrendezésű szerkezet szinte megegyezik kb. 35\%-os cellatérfogat-részarány szintig, majd e cellatérfogat-részarány szint alatt a lapközepes köbös elrendezésü szerkezet egyenértékű feszültségei emelkedni kezdtek. A lapközepes, térközepes köbös elrendezésű szerkezet, valamint a gyémántrács alapú szerkezet nyílt és zárt cellás szerkezetet is tartalmazhat. Mindháromnál jól látható, hogy hol válik a nyílt cellás szerkezetből zárt cellás szerkezet. Jól látható az egyenértékű feszültségek növekedése, ami abból következik, hogy a nyílt cellás szerkezetté válás a testmodellekben elvékonyodott falakkal jár.

Tanulmányunkban olyan cellaszerkezeteket vizsgáltunk, melyek felépítése leképezi a köbös elemi cellájú kristályrácsok atomelrendezését. Vizsgáltuk az egész testben ébredő, valamint a középső építőegység térfogatában ébredő egyenértékű feszültség értékeit. Összesítésben a térközepes köbös szerkezeti forma esetében kaptuk a legjobb megoldást. A számításokat empirikus módon validálni fogjuk, additív gyártással előállított próbatesteken is.

\section{Köszönetnyilvánítás}

Ezúton szeretnénk köszönetet mondani Dobránszky Jánosnak a tanulmány írásában nyújtott segítségéért.

\section{Szakirodalmi hivatkozások}

[1] Butscher A., Bohner M., Hofmann S., Gauckler L., Müller R.: Structural and material approaches to bone tissue engineering in powder-based three-dimensional printing. Acta Biomaterialia, 7/3. (2011) 907-920.

https://doi.org/10.1016/j.actbio.2010.09.039

[2] Hollister S. J.: Porous scaffold design for tissue engineering. Nature Materials, 5/7. (2005) 518-524. http://doi.org/10.1038/nmat1421

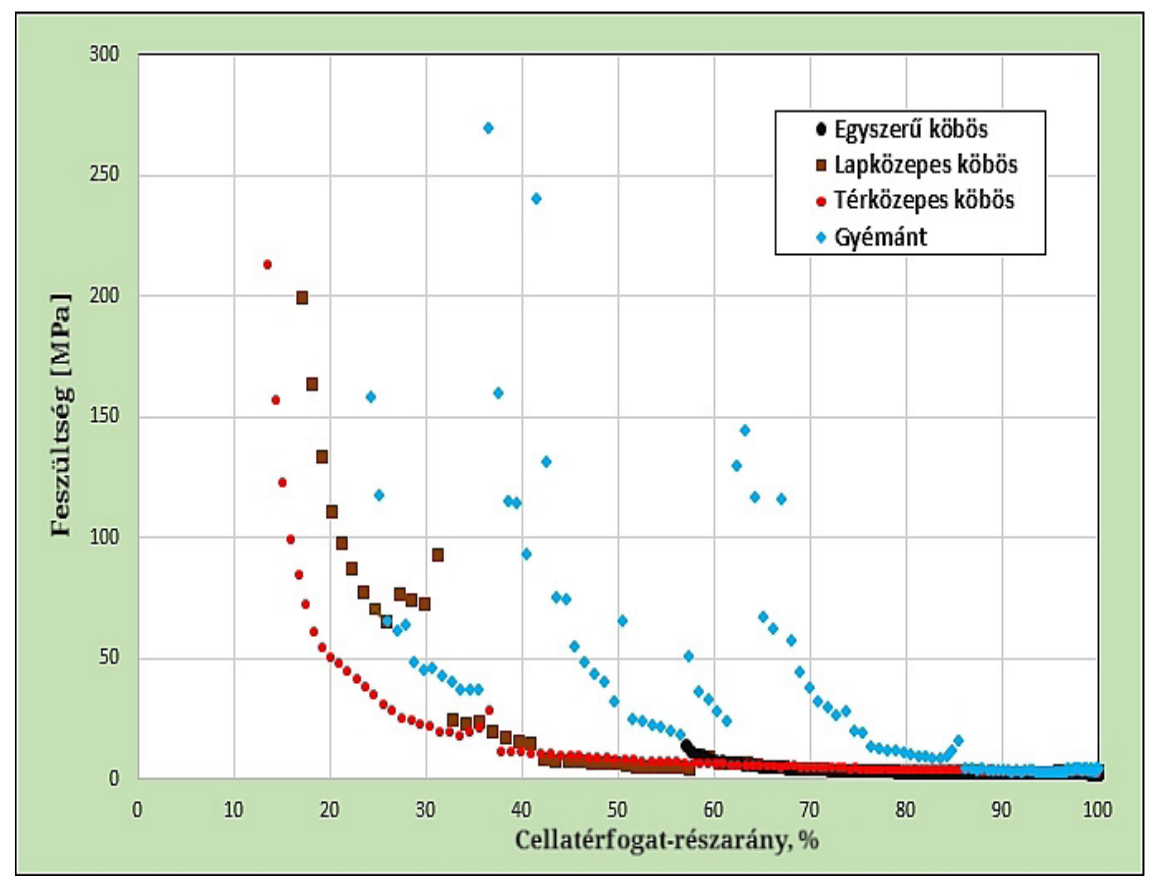

14. ábra. Az eredmények szemléltetése 
[3] Hutmacher D. W.: Scaffold design and fabrication technologies for engineering tissues - state of the art and future prespectives. Journal of Biomaterials Science, Polymer Edition, 12/1. (2001) 107-124. https://doi.org/10.1163/156856201744489

[4] Goulet R. W., Goldstein S. S., Ciarelli M. J. et al.: The relationship between the structural and orthogonal compressive properties of trabecular bone. Journal of Biomechanics, 7/4. (1994) 379-389. https://doi.org/10.1016/0021-9290(94)90014-0

[5] Ahmadi S. M., Campoli G., Yavari S. A. et al.: Mechanical behavior of regular open-cell porous biomaterials made of diamond lattice unit cells. Journal of the Mechanical Behavior of Biomedical Materials, 34/1. (2014) 106-115. https://doi.org/10.1016/j.jmbbm.2014.02.003

[6] Engh C. A., Bobyn J. D., Glassman A. H.: Porous-coated hip replacement. The factors governing bone ingrowth, stress shielding, and clinical results. The Journal of Bone and Joint Surgery, 69-B/1. (1987) 45-55. https://doi.org/10.1302/0301-620X.69B1.3818732

[7] Huiskes R., Weinans H., van Rietbergen B.: The relationship between stress shielding and bone resorption around total hip stems and the effects of flexible materials. Clinical Orthopaedics and Related Research, 274/1. (1992) 124-134. https://doi.org/10.1097/00003086-19920100000014

[8] Amin Yavari S., Ahmadi S. M., van der Stock J. et al.: Effects of bio-functionalizing surface treatments on the mechanical behavior of open porous titanium biomaterials. Journal of the Mechanical Behavior of Biomedical Materials, 36/1. (2014) 109-119.

https://doi.org/10.1016/j.jmbbm.2014.04.010
[9] Van der Stock J., Van der Jagt O. P., Amin Yavari S., et al.: Selective laser melting-produced porous titanium scaffolds regenerate bone in critical size cortical bone defects. Journal of Orthopaedic Research, 31/5. (2013) 792-799.

https://doi.org/10.1002/jor.22293

[10] Gibson I., Rosen D. W., Stuckre B.: Additive Manufacturing Technologies. Rapid Prototyping to Direct Digital Manufacturing. Springer, New York, 2010. 6-9.

[11] Vandebroucke B., Kruth J. P.: Selective laser melting of biocompatible metals for rapid manufacturing of medical parts. Rapid Prototyping Journal, 13/4. (2007) 196-203.

https://doi.org/10.1108/13552540710776142

[12] Li Y., Yang C., Zhao H. et al.: New Developments if Ti-Based Alloys for Biomedical Applications. Materials, 7/3. (2014) 1709-1800. https://doi.org/10.3390/ma7031709

[13] Zysset P. K., Guo X. E., Hoffler C. E.: Elastic modulus and hardness of cortical and trabecular bone lamellae measured by nanoindentation in the human femur. Journal of Biomechanics, 32/10. (1999) 1005-1012. https://doi.org/10.1016/S0021-9290(99)00111-6

[14] Ahmaid S. M., Yavari S. A., Wauthle R.: Additively Maufactured Open-Cell Porous Biomaterials Made from Six Different Space-Filling unit Cells: The Mechanical and Morphological Properties. Materials, 8/4. (2015) 1871-1896. https://doi.org/ 10.3390/ma8041871

[15] Chen S. Y., Huang J. C., Pan C. T.: Microstructure and mechanical properties of open-cell porous Ti-6Al-4V fabricated by selective laser melting. Journal of Alloys and Compounds, 713. (2017) 248-254.

https://doi.org/10.1016/j.jallcom.2017.04.190 